\title{
PELAKSANAAN LELANG BARANG SITAAN OLEH KOMISI PEMBERANTASAN KORUPSI
}

Gokma Toni Parlindungan S

Sekolah Tinggi Ilmu Hukum Padang, Padang

gokmatoni@gmail.com

\begin{abstract}
ABSTRAK
Kerugian negara akibat tindak pidana korupsi masih belum tertutupi dan keresahan masyarakat masih tinggi terhadap penegakan hukum atas tindak pidana di Indonesia. Korupsi sering disebut extra ordinary crime, sering kali tindak pidana korupsi ini diidentikkan dengan white collar crime yaitu suatu perbuatan (tidak berbuat) dalam sekelompok kejahatan yang spesifik yang bertentangan dengan hukum pidana yang dilakukan oleh pihak professional, baik oleh individu, organisasi, atau sindikat kejahatan, ataupun dilalaikan oleh badan hukum. Untuk pengembalian aset negara akibat korupsi, Komisi Pemberantasan Korupsi (KPK) membuka lelang eksekusi barang rampasan kasus rasuah. Mayoritas aset yang dilelang berupa kendaraan. Bahkan, sebagian masuk golongan mobil mewah senilai ratusan juta hingga miliaran rupiah. Total ada 22 aset yang masuk daftar lelang oleh KPK. Persoalan asset recovery untuk meminimalkan kerugian negara merupakan merupakan faktor yang tak kalah penting dari upaya pemberantasan korupsi di samping memvonis pelaku dengan hukuman yang seberat-beratnya. Langkah untuk meminimalkan kerugian negara tersebut di samping harus dilakukan sejak awal penganan perkara dengan pembekuan dan penyitaan, juga mutlak dilakukan melalui kerja sama dengan negara lain di mana hasil kejahatan (proceeds of crime) berada.
\end{abstract}

Kata Kunci: Pelaksanaan, Lelang, Barang Sitaan, KPK, Korupsi.

\section{ABSTRACT}

State losses due to crim inal acts of corruption are still not covered and public unrest is still high against law enforcement for criminal acts in Indonesia, corruption is often called an extraordinary crime, often this crime of corruption is identified with the white collar crime which is an act (not doing) in a group of specific crimes that are contrary to criminal law carried out by professional parties, either by individuals, organizations, or criminal syndicates, or carried out by legal entities. For the return of state assets due to corruption, the Corruption Eradication Commission (KPK) opened an auction for the execution of a major booty case. The majority of assets auctioned are vehicles. In fact, some enter the class of luxury cars worth hundreds of millions to billions of rupiah. In total there are 22 assets that are listed in the auction ini KPK. The issue of asset recovery to minimize state losses is an equally important factor in efforts to eradicate corruption in addition to convicting the perpetrators with the most severe penalties. The steps to minimize the state's losses in addition to having to be carried out since the beginning of confiscation cases with feezing and confiscation are also absolutely carried out through cooperation with other countries where the proceeds of crime are located.

Keywords: Implementation, Auction, Confiscated Goods, KPK, Corruption.

\section{PENDAHULUAN}

Korupsi telah menjadi penyakit yang muncul perlahan-lahan sebagai momok yang dapat membawa kehancuran bagi perekonomian Negara. Diakui atau tidak, praktik korupsi yang terjadi dalam bangsa ini telah menimbulkan banyak kerugian. Tidak saja bidang ekonomi, maupun juga dalam bidang politik,, sosial budaya, maupun keamanan (Deni Styawati, 2008). Korupsi menjadi salah satu masalah besar yang dihadapi Indonesia, bahkan telak kronis. Korupsi di Negara ini bahkan telah merambah semua ini bagaikan gurita. Penyimpangan ini bukan saja merasuki lorong-lorong instansi yang tidak, terbayangkan sebe lumnya bahwa disana ada korupsi (Achmad Zainuri, 2007). Secara 
etimologis atau menurut bahasa," korupsi berasal dari bahasa latin corruptio atau conuptus, dan bahasa latin yang lebih tua dipakai istilah corrumpere. Dari bahasa latin itulah turun ke berbagai bahasa bangsa-bangsa di Eropa. Seperti Inggris: corruption, corrupt; Prancis: conuption; dan Belanda: corruptive atau korruptie, yang kemudian turun ke dalam bahasa Indonesia menjadi koiupsi." Arti kata i hi ialah kebusukan, keburukan, kebejatan, ketidakjujuran, dapat disuap, ti'dak bermoral, penimpangan dai'i kesucian (Andi hamzah, 1991).

Penegakan hukum yang dilakukan secara konvensional untuk memberantas tindak pidana korupsi terbukti mengalami berbagai hambatan. Unhik ihi diperlukan metode penegakan hukum yang luar biasa nrela lui pembentukan suatu badan khusus yang mempunyai kewenangan luas, independen, serta bebas dari ketatasaan nranapun dalam upaya pemberantasan tindak pidana koiupsi, yang pelaksanaanya dilakukan dalam upaya tindak pidana koiupsi, yang pelaksanaanya dilakukan secara optimal, intensif, efektif profesional, serta berkesinambungan (Harkrishiti Harkrisnowo, 2003). Nyoman Serikat Putra Jaya (2008) menyata'kan bahwa perkembangan tindak pidana koiupsi baik dilihat dai'i sisi kuantitas maupun sisi foialitas dewasa ini dapat dikatakan bahwa koiupsi di Indonesia tida'k lagi melupakan kejahatan biasa ( - ordinary crimes), akan tetapi sudah merupakan kejahatan 'luar biasa \{extra ordinary crimes). Mengingat kompleksitas serta efek negatifnya, maka koiupsi yang dikategorikan sebagai kejahatan yang luar biasa (extra ordinary Climes) memerlukan upaya pemberantasan dengan cara-cara yang luar biasa \{extra ordinary measure).

Disamping tindak pidana koiupsi sering disebut extra ordinary scrime, sei'ing kali tindak pidana korupsi ini diidentikkan dengan white collar crime yaitu suahi perbuatan (tidak bei'buat) dalam sekelompok kejahatan yang spesifik yang bertentangan dengan hukum pidana yang dilakukan oleh pihak professional, baik oleli individu, organisasi, atau sindikat kejahatan, ataupun dilakukan oleli badan hukum. Menurut Dony Kleden Rohaniwan, kejahatan kerah putih (white collar crime) adalah istilah temuan Hazel Croal untuk menyebut berbagai tindak kejahatan di lembaga 'pemerintahan yang teijadi, baik secara stiuktural yang melibatkan sekelompok orang nraupun secara ind'ividu. Jlazel Croal mendifinisikan kejahatan kerah putih sebagai penyalahgunaan jabatan yang legitim sebagaimana ditetapkan oleh hukum. LJmumnya, skandal kejahatan kerah putih sulit dilacak karena dilakukan pejabat yang punya kuasa untuk memproduksi hukum dan membuat berbagai keputusan vital (Laurensius Arliman s, 2016).

Sebagaimana diamanatkan dalam Pasal 43 Undang-Undang Nomor 31 Tahun 1999 tentang Pemberantasan Tindak Pidana Korupsi, sebagaimana diubah dengan LJndang- Undang Nomor 20 Tahun 2001 tentang tentang Perubahan atas Undang-Undang Nomor 31 Tahun 1999 tentang Pemberantasan Tindak Pidana Koiupsi selanjutnya disebut UU Tipikor, KPK dibentuk berdasarkan Undang-Undang Nomor 30 Tahun 2002 tentang Komisi Pemberantasan Pidana Korupsi. KPK, diberi amanat melakukan pemberantasan korupsi secara profesional, intensif, dan berkesinambungan. KPK melupakan lem'baga negara yang bersifat independen, yang dalam melaksanakan tugas dan wewenangnya bebas dari kekuasaan manapun (Laurensius Arliman s, 2018).

Adapun tugas KPK yang adalah koordinasi dengan instansi yang berwenang a) melakukan pemberantasan tindak pidana korupsi (TPK); b) supervisi terhadap instansi yang berwenang melalmkan pemberantasan TPK; c) melakukan penyelidikan, penyidikan, dan penuntutan terhadap TPK; d) melakukan tindakan- tindakan pencegahan TPK; dan e) melakukan monitor terhadap penyelenggaraan pemerintahan negara. Dalam pelaksanaannya mgasnya, KPK be^edoman kepada 'lima asas, yaitu: kepastian hulmm, keterbukaan, akuntabilitas, kepentingan umtrm, dan proposionalitas. KPK bertanggung jawab kepada publik dan menyampaikan laporannya secara terbuka 
dan berkala kepada presiden, DPR, dan BPK. KPK dipimpin olelr Pimpinan KPK yarrg terdiri atas linra orang, seorairg ketua merangkap anggota dan empat orang wakil ketua merangkap anggota. Kelima pimpinan KPK tersebut melupakan pejabat negara, yang berasal dari unsur penrerintahan dan unsur masyarakat. Pimpinan KPK nremegang jabatan selama empat tahun dan dapat dipilih kembali hanya unrnk sekali masa jabatan. Dalam pengambilan kepunrsan, pimpinan KPK bersifat kolektifkolegial (Purwaning M. Yanuar, 2007).

Pimpinan KPK membawahkan empat bidang, yang terdiri atas bidang Pencegahan, Penindakan, Informasi dan Data, seria Pengawasan Internal dan Pengaduan Masyarakat. Masingmasing bidang tersebut dipimpin olelr seorang deputi. KPK juga dibantu Sekretariat Jenderal yaitg dipimpin seorang Sekretaris Jenderal yang diangkat dan diberhentikan oleh Presiden Republik Indonesia, namun bertang $\wedge^{m g}$ jawab kepada pimpinait KPK. Ketentuan mengenai struktur organisasi KPK diatur sedemikiarr rupa sehingga memungkinkan masyarakat luas tetap dapat berpartisipasi dalam aktivitas dan langkah-langkah yang dilakukan KPK. Dalam pelaksanaan operasional, KPK mengangkat pegawai yang direkrut sesuai kompetensi yang diperlukan (Laurensius Arliman s, 2016). Terkait pembahasan di atas salah satu tindak pidana terbesar di Indonesia yaitu korupsi, tindak pidana korupsi (tipikor.) sudah diaUrr dalam Undang-Undang No. 31 Tahun 1999 jo. Undang-Undang No. 20 Tahun 2001 (UU Tipikor). Pasal 2 ayat (1) UU Tipikor menyebutkan: "setiap orang yang secara melawan hukum melakukan perbuatan memperkaya diri sendiri atau orang lain atau suatu korporasi yang dapat merugikan keuangan negara atatr perekonomian negara dipidana dengan pidana penjara minimal 4 tahun dan maksimal 20 tahun dan denda paling seddrit 200 juta rupiah darr paling banyak 1 miliar rupiah."

Lebih lanjut. Pasal 3 menyebutkan: "setiap orang yang dengan tujuan menguntungkan diri sendiri atair orang lain atau suatu korporasi, menyalahgunakan kewenangan, kesempatan atau saraira yang ada padanya karena jabatan atau karena kedudukan yang dapat merugikan keuangan negara atau perekonomian iregara dipidana seumur, hidup, atau pidana penjara paling singkat 1 tahun dan paling lama 20 tahun dan atau denda paling sedikit 50 juta rupialr dan maksimal 1 miliar-." Meningkatnya tindak pidana korupsi yang tidakterkendali akan membawa bencana, tidak saja bagi kehidupan perekonomian nasional, juga pada kehidupan berbangsa dan bernegara. Ilasil survey Transparency International Indonesiaan. (TII) menunjukkan, Indonesia mempakan negara pa'ling korup nomor enam dari 133 negara. Di kawasan Asia, Bangladesh dan Myanmar- lebih korup dibanding Indonesia. Nilai Indeks Persepsi Korupsi (IPK) Indonesia ternyata lebili rendah daripada negara-negara tetangga, seperti Papua Nugini, Vietnam, Filipina, Malaysia dan Singapura (Gokma Toni Parlindungan s, 2017).

Secara yuridis normatif berbagai peraturan perundang-undangan sebagai sarana pemberantasan korupsi sudah memadai, di antaranya yaitu UU No. 28 Tahun 1999 tentang Penyelenggaraan Negara yang bersih, dan bebas dari korupsi, dan UU No. 31 Tahun 1999 tentang Pemberantasan Tindak Pidana Korupsi, yang telah dirtibah UU Tipikor, UU No. 30 Tahun 2002 tentang Komisi Pemberantasan Tindak Pidana Korupsi dengan sistem operasi Tangkap Tangan, Instruksi Presiden No. 5 Tahun 2004 tentang Percepatan Pemberantasan Konrpsi, dan Kepuhisan Presiden No. 11 Talrun 2005 tentang Tim Koordinasi Pemberantasan Tindak Pidana Korupsi. Akan tetapi bagaimana efektivitasnya, peraturan perundang-undangan dengan keterrtuan normanya hanya bisa implementatifbila digerakkan oleh penegakan hukum (Gokma Toni Parlindungan s, 201-4).

Sehubungan dengan pembahasan di atas, menurut E.Y Kanter dan s. R Sianturi (2002) pendayagunaan Undang-Undang Tipikor termasuk sebagai kebijakan kriminal. Istilah kebijakan 
berasal dari bahasa Inggris yakni policy atau dalam bahasa Belanda politik yang secara umum dapat diartikan sebagai prinsip-prinsip umrrm yang berftrngsi untuk mengarahkan pemerintah (dalam arti luas termasrrk pula aparat penegak hukum dalam mengelola, mengatur, atau menyelesaikan urusanurusan publik, masalah-masalah masyarakat atau bidang-bidang penyusunan peraturan perundangundangan dan pengaplikasian hukum/peraturan, dengan tujuan (umum) yatrg mengarah pada upaya mewujudkan kesejahteraan atarr kemakmuran masyarakat (warga negara).

Bar.da Nawawi. Arif (2010) mengemrrkakan: sebagai usaha yang rasional dari masyarakat untuk menanggulangi kejahatan. Di dalamnya mencakup kebijakan hukum pidana yang disebtit juga sebagai kebijakan penanggulangan kejahatan dengan hukum pidana, yang dalam arti paling luas merupakan keseluruhan kebijakan yang dilakukan melalui perundang-undangan dan badan resmi, yang bertujuan untuk menegakkan nonna- norma sentral dari masyarakat. Perencanaan penanggulangan kejahatan diperlukan agar, perundang-undangan pidana menjadi sarana yang baik untuk menanggulangi tindak pidarra korupsi dan berlaku efektif. Kegiatan ini mernas'uki lingkup kebijakan hukum pidana, yang merarpakan suatrr proses terdiri dari tahap formulasi atau legislatif, tahap peneraparr atau yudikatif, dan tahap pelaksanaan atau eksekutif/administratif. Masalah korupsi bukan lagi masalah baru dalam persoalarr hukum dan ekonomi bagi suaUr negara karena masalalr korupsi telah, ada sejak ribuan tahun, baik di negara maju maupun di negara berkembang termasrrk juga di Indonesia (Adrian Sutendi, 2010).

Kerugian negara akibat tindak pidana korupsi masih belu'm terhrhrpi dan keresalran masyarakat masilr tinggi terhadap penegakarr Irukrrm atas tindak pidarra di Indonesia. Pemidanaan merupakan salalr satrr elemen hukum yang paling penting dalam penegakan hrrkum pidana. Hrrkum pidana tanpa mengaitkannya dengan penridanaan bagaikan macan tanpa gigi. Penjatuhan hukuman pidana olelr perrgadilan merupakan suahr upaya yang sah, yang dilandasi oleh hukum unhrk mengenakan nestapa atarr penderitaan terhadap seseorang yang terbukti bersalah nrelakukan tindak pidana. Pidana sendiri merupakan suahr pranata sosial yang di.kaitkan dengan, dan selalu mencerminkan, nilai dan struktur masyarakat.

sehingga merupakan suatu reafirmasi simbolis atas pelanggaran terhadap "hati nurani bersama" atau collective conscience, meminjam terminologi Emile Durkheim (Gokma Toni Parlindungan S, 2013).

Pidana penjara yang merupakan jenis pidana pokok yang paling popular diantara pidana pokok lainnya (berdasarkan Pasal 10 Kitab Undang-Undang Hukum Pidana) memang efektif memberi pembalasan kepada para terpidana atas tindak pidana korupsi yang terbukti dilakukannya. Akan tetapi, pidana penjara tidak selalu menyelesaikan masalah, malah dapat menimbulkan masalah seperti over capacity, ketidakjeraan koruptor, dan kerugian negara tidak kunjung terselesaikan. Konsep tujuan pemidanaan yang berkembang selama ini dianggap memiliki berbagai kelemahan terutama karena dianggap sama sekali tidak memberikan keuntungan apapun bagi korban dan masyarakat. Hal ini diperkuat lagi dengan adanya perkembangan pemikiran masyarakat terhadap hukum pidana di berbagai belahan dunia. Roeslan Saleh menyatakan bahwa Hukum Pidana merupakan kaca yuridis yang paling peka terhadap perubahan budaya, keadaan sosial yang pada umumnya dalam semua keadaan dimana ada manusia. Perkembangan pemikiran tentang hak asasi manusia telah membawa pembahan besar terhadap masyarakat dalam memandang suatu hal yang berkaitan dengan hidup dan kehidupannya. Tak terkecuali pandangan terhadap pidana dan pemidanaan. Pidana dan pemidanaan yang pada dasarnya memberikan pembenaran atas penjatuhan satu derita kepada seseorang akibat suatu tindak pidana yang dilakukannya sepintas lalu akan bertolak belakang dengan konsep-konsep yang ada dalam hak asasi manusia yang justru memberikan perlindungan terhadap hak asasi manusia. 
Undang-Undang Nomor 31 tahun 1999 jo Undang-Undang Nomor 20 Tahun 2001 sebenarnya sudah berani dan "menggigit" mengatur mengenai pemberantasan korupsi dan pemidanaan para pelaku tindak pidana korupsi, bahkan penjatuhan dua pidana pokok sekaligus diperbolehkan. Dengan keistimewaan dalam penjatuhan pidana terhadap tindak pidana kompsi berarti pemidanaan diharapkan menjadi hal yang berpengaruh sangat kuat dalam penegakan hukum dan pemberantasan korupsi. Berangkat dari pasal 4 Undang- undang No. 31 tahun 1999 jo Undang-undang No 20 tahun 2001 tentang Pemberantasan Tindak Pidana Korupsi yang mengamanatkan bahwa "Pengembalian kerugian keuangan negara atau perekonomian negara tidak menghapuskan dipidananya pelaku tindak pidana" perampasan aset hasil korupsi sendui sebenarnya telah diadopsi oleh Indonesia, tetapi Indonesia lagilagi bukan negara yang dengan mudah dapat menyesuaikan suatu perubahan sistem, apalagi yang berhubungan dengan bidang penegakan hukum. Pengaruh kolonial masih sangat kental dalam sistem hukum Indonesia karena walaupun Rancangan KUHP telah disusun sejak tahun 1994 dan direvisi beberapa kali, hingga saat ini, tahun 2011, Rancangan KUHP tersebut belum juga disahkan untuk menggantikan KUHP, warisan Belanda puluhan tahun lalu, yang sampai saat ini masih kita gunakan (Romli Atmasasmita, 2008).

Persoalan as $s$ et recovery untuk meminimalkan kerugian negara merupakan merupakan faktor yang tak kalah penting dari upaya pemberantasan korupsi di samping memvonis pelaku dengan hukuman yang seberat-beratnya. Langkah untuk meminimalkan kerugian negara tersebut di samping harus dilakukan sejak awal penganan perkara dengan 
pembekuan dan penyitaan, juga mutlak dilakukan melalui keija sama dengan negara lain di mana hasil kejahatan (proceeds of crime) berada. Untuk itu ..rientasi penegak hukum ,mengenai pengembalian aset ini perlu dipertajam terutama dalam hubungan kerja sama dengan negara lain baik melalui pertukaran informasi intelijen keuangan yang difasilitasi oleh PPATK, koordinasi dengan Tim Pemburu Koruptor, maupun kerja sama bantuan hukum timbal balik antara pemerintah kita dengan pemerintah negara lain.

\section{METODE PENELITIAN}

Menurut B ambang Surrggono, penelitian pada dasarnya meiupakan, "suatu upaya pencariair" dan bukannya sekedar mengamati dengan teliti terhadap sesuatu obyek yang mudah terpegang di tairgan. Penelit'ian merupakan terjemahan dari balrasa Inggris yaitu 'research, yang berasal dari kata re (kem'bali) dan to search (mencari). Derrgan demikian secara logawiyah berarti "mencari kembali". Penelitian merupakan suahr sarana pokok dalam pengembangan ilmu pengetahuan maupun teknologi. Hal ini disebabkan, oleh karena penelitian bertujuan untuk menyingkapkan kebenaran secara sistematis, metodologis, dan konsisten. Melalui pi'oses penelitian tersebut diadakan analisa dan konstruksi terhadap data yang telah dikumpulkan dan diolah (/ Soerjono Soekanto dan Sri Mamudji, 2011). Dalam penyisunan penelitian ini, dibuhihkan bahan atau data penelitan yang dilakukan olelr peneli'ti yang terjadi dilapangan, ser'ta bahan atati data yang konkrit berasal dari bahan kepustakaan. Penelitian karya ilmiah ini, berjenis penelitian hukum normatif (yuridis normati)/. !yaitu penelitian yang bertujuan untuk 'meneliti asas-asas hukum, sistematika hukum, sinkronisasi hukum, sejarah hukum dan perbandingan hukum (Zainuddin Ali, 2010). Pada, penelitian yuridis normatif penelitian in,i difokuskan untuk mengkaji dan meneliti materi hukum tentang pelaksanaan lelang barang sitaan oleh Komisi Pemberantasan Korupsi

\section{HASIL PENELITIAN DAN PEMBAHASAN}

\section{A. Konsep Barang Sitaan dan Lelang Oleh Komisi Pemberantasan Korupsi}

Lelang atau Penjualan dimuka umum adalalr suatu penjualan barang yang dilakukan didepan khalayak ramai dimarra harga barang-barang yang ditawarkan kepada pembeli setiap saat semakin meningkat. Selain itu, pasal 1 Vendu Reglement (VR) yang merupakan aUrran pokok lelang yang dibawa oleh belanda menyebutkan: "penjualan umum (lelang) adalali penjualan barang- barang yang dilakukan kepada umum dengan penawaran $h$,arga yang meningkat atau dengan .pemasukan harga dalam sampul tertutup, atau kepada orang-orang yang diundang atau sebelumirya d'iberitahu mengenai pelelangan atau penjualan itu, ata'u diizirrkan untuk ikut-serta, dan diberi kesempatan untuk menawar harga, menyetujui harga yang ditawarkan atau menrasukkan harga dalarrr sampul tertutup" (Salim HS, 2011).

Rahmat Soemitro di dalam bukunya, yang di kutip dari Polderjnan menyatakan bahwa penjualan mnum adalah alat uni mengadakan peijanjian atau persetujuan yang paling menguntungkan untuk si penjual dengan cara menghimpun para peminat. Poldeiman selanjutnya mengatakan bahwa yang merupakan syarat utama adalah menghimpun para peminat untuk mengadakan perjanjian jual beli yang palhrg menguntungkan si penjual ( $R$,ahmat Soemitro, 1987).

Selain itu, menurtrt Roell,

menyebutkan bahwa penjualan umum adalah suatu rangkaian kejadian yang terjadi antara saat dimana seseorang hendak menjual satu atau lebih dari suatu barang, baik secara pribadi ataupun dengan perantaraan kuasanya memberi kesempatan kepada orang-orang yang hadir melakukan penawaran untuk membeli barang-barang yang ditawarkan sampai kepada saat dimana kesempatan lenyap, 
ditambahkan bahwa penjualan itu adalah secara sukarela kecuali jika dilakukan atas perintah hakim (Gokma Toni Parlindungan S, 2017).

Artinya, saat ini Lelang dapat dilakukan dengan menggunakan media elektronik melalui internet atau Lelang Online.Dalam peraturan Menteri Keuangan, yang dimaksud dengan Lelang adalah penjualan barang yang terbuka untuk umum dengan penawaran harga secara tertulis dan/atau lisan yang semakin meningkat atau menurun untuk mencapai harga tertinggi yang didahului dengan pengumuman lelang. Maka dengan demikian, syarat dari penjualan umum secara garis besar adalah hanya ada dua, yaitu: 1) Pengumpulan para peminat; 2) Adanya kesempatan yang diberikan untuk mengajukan penawaran yang bersaing seluas-luasnya.

Mengenai barang sitaan menurut Pasal 1 butir 16 dinyatakan: "Penyitaan adalah serangkaian tindakan penyidik untuk mengambil alih dan atau menyimpan dibawah penguasaannya benda bergerak atau tidak bergerak, berwujud atau tidak berwujud untuk kepentingan pembuktian dalam penyidikan, penuntutan, dan peradilan". Berkaitan dengan penyitaan maka benda yang dapat disita antara lain: 1) Benda atau tagihan tersangka atau terdakwa yang seluruh atau sebagian diperoleh dari tindak pidana atau sebagian hasil dari tindak pidana; 2) Benda yang telah digunakan secara langsung untuk melakukan tindak pidana atau mempersiapkannya; 3) Benda yang digunakan untuk menghalanghalangi penyidikan tindak pidana; 4) Yang dibuat khusus untuk melakukan tindak pidana; 5) Dan benda lain yang berhubungan langsung dengan tindak pidana yang dilakukan.

Kelima benda tersebut dapat digunakan dan dikategorikan sebagai alat bukti dan berfungsi dalam proses pemeriksaan suatu perkara pidana, sehingga dalam proses mendapatkan alat bukti dan menyitanya serta menempatkan barang sitaan tersebut diperlukan suatu tempat yang merupakan pusat penyimpanan segala macam barang sitaan. Mengenai tempat penyimpanan benda sitaan negara sebagai barang bukti di dalam perkara pidana, di dalam Kitab Undang-Undang Hukum Acara Pidana (KUHAP) terdapat dalam Pasal 44 ayat (1) yang berbunyi: "Benda Sitaan Negara disimpan dalam Rumah Penyimpanan Benda Sitaan Negara".

Di wilayah Surakarta terdapat suatu Rumah Penyimpanan Benda Sitaan Negara, namun fungsi dan peranannya belum dapat dikatakan maksimal, dikarenakan belum terciptanya suatu kebijakan fungsional yang menetapkan bahwa diperlukannya Rupbasan dalam suatu proses peradilan perkara pidana menyangkut dengan penyimpanan alat-alat bukti yang selama ini dicitra masyarakat umum Rupbasan belum berfungsi dengan baik berkaitan dengan penjagaan, penyimpanan, pengamanan, dan penyelamatan benda-benda sitaan. Secara struktural dan fungsional, Rupbasan berada di bawah lingkungan Departemen Kehakiman yang akan menjadi pusat penyimpanan segala macam barang sitaan dari berbagai instansi. Pendirian Rupbasan didasari oleh 
Pasal 44 ayat (1) KUHAP dan juga PP No. 27 Tahun 1983 serta Peraturan Menteri Kehakiman No. M.05.UM.01.06 Tahun 1983. Sehubungan dengan apa yang disebut RUPBASAN yang diatur dalam Kitab Undang-Undang Hukum Acara Pidana, PP No.27 Tahun 1983 serta Peraturan Menteri Kehakiman No. M.05.UM.01.06 Tahun 1983, pada kenyataannya belum jelas mengenai pengaturan pelaksanaannya.

Untuk memperjelas pelaksanaannya, perlu diketahui bagaimana Mekanisme Pelaksanaan Pengelolaan Benda Sitaan Negara dan Barang Rampasan Negara di Rupbasan, sehingga kemudian hal itu diatur dalam SK Direktur Jenderal Pemasyarakatan No. E1.35.PK.03.10 Tahun 2002 tentang Petunjuk Pelaksanaan dan Petunjuk Teknis Pengelolaan Benda Sitaan Negara dan Barang Rampasan Negara di RUPBASAN, sebagai penjabaran dari Peraturan Menteri Kehakiman No. M.05.UM.01.06 Tahun 1983. Agar dalam Pelaksanaan Pengelolaan Benda Sitaan Negara dan Barang Rampasan Negara di Rupbasan dapat berjalan sesuai fungsinya, maka diperlukan suatu keija sama yang baik dari berbagai instansi yang berkaitan seperti Pengadilan, Kepolisian dan Kejaksaan serta instansi lainnya untuk menyerahkan benda-benda sitaan untuk disimpan di Rupbasan agar keamanannya dapat terjaga dan terlindungi serta apabila dalam proses pengadilan putusan agar dikembalikan maka dapat dikembalikan secara utuh tanpa cacat ataupun rusak (Gokma Toni Parlindungan S, 2016).

\section{B. Pelaksanaan Lelang Barang Sitaan Oleh Komisi Pemberantasan Korupsi}

Mengingat tindak pidana korupsi dikategorikan sebagai kejahatan luar biasa dan sangat mungkin menjadi kejahatan transnasional, maka Majelis Umum Perserikatan Bangsa-Bangsa (PBB) dengan suara bulat telah mengadopsi United Natioiis Convention Against Corruption 2003 pada tanggal 30 September 2003. United Nations Convention Against Corruption dibuka untuk penandatanganan dalam Konferensi Politik Tingkat Tinggi dengan Tujuan Penandatanganan United Nations Convention Against Corruption di Merida, Meksiko, tanggal 9-11 Desember 2003. United Nation Convention Against Corruption merupakan salah satu hasil dari upaya masyarakat internasional dalam hal pemberantasan tindak pidana korupsi. Pemerintah Indonesia ikut aktif sejak sidang pertama sampai dengan sidang ketujuh (terakhir) yang berakhir pada tanggal 1 Oktober 2003. Negara Peserta United Nations Convention Against Corruption 2003 mencapai sebanyak 127 negara, dari jumlah tersebut 99\% telah menyatakan kesediaannya untuk menandatangani konvensi tersebut. Dasar pertimbangan keikutsetaan Indonesia dalam penandatanganan konvensi tersebut mengenai implikasi hukum peratifikasian konvensi tersebut ke dalam sistem hukum nasional (UNPress Release, 2003).

Salah satu pembahasan penting yang diatur dalam UNCAC 2003 ini adalah mengenai hal pengembalian aset (Asset Recovery). Ruang gerak koruptor para koruptor untuk bersembunyi dan melarikan hasil kejahatannya ke sejumlah negara kian sempit. Dengan disahkannya Konvensi PBB ini korupsi diakui sebagai kejahatan global dan akan ditangani dengan semangat kebersamaan. Sebenarnya sudah lama korupsi dinobatkan sebagai extra-ordinary crime, balikan sebelum disahkannya UNCAC 2003. Indonesia termasuk negara yang ikut menandatangani konvensi tersebut. Pada pasal 3 tentang Scope application, ayat (1) tentang cooperation with law enforcement

authorities, ditegaskan bahwa, "Each state party shall take appropriate measure to encourage persons who participate or who have participate in the commission of an offense establish in accordance with this convention to supply information useful to competen t authorities for investigative and eviden tiary purposes and to provide factual, specific help to competent that may contribute to such depriving 


\section{offenders of the proceeds of crime and recovering such proceeds."}

Walaupun perangkat hukum internasional yaitu UNCAC telah diratifikasi oleh Indonesia dengan Undang-Undang No. 7 Tahun 2006 tentang Pengesahan UNCAC, pengembalian aset hasil korupsi belum juga diterapkan. Sehubungan dengan masalah tersebut, Barda Nawawi Arif di dalam suatu seminar pernah menyatakan: "Bahwa tujuan dari kebijakan menerapkan suatu sanksi pidana tidak dapat dilepaskan dari tujuan politik kriminil dalam arti keseluruhannya yaitu Perlindungan Masyarakat untuk mencapai kesejahteraan." (tujuan demikian nampaknya disepaati oleh seluruh anggota UNAFEI ('United Nations Asia and Far East Institute) dimana Indonesia merupakan salah satu anggotanya).

Menurut Matthew H. Flemming dalam dunia internasional, tidak ada definisi pengembalian aset yang disepakati bersama, Flemming sendiri tidak mengemukakan rumusan definisi, tetapi menjelaskan bahwa pengembalian aset adalah proses pelaku- pelaku kejahatan dicabut, dirampas, dihilangkan haknya dari hasil tindak pidana dan/atau dari sari sarana tindak pidana. United Nations Convention Against Corruption tidal !secara tegas menyatakan apakah penyitaan merupakan hukuman !penalty seperti didefinisikan dalam Konvensi tentang Pencucian, Pelacakan, Perampasan dan Penyitaan atas Hasil-hasil Kejahatan dari Dewan Eropa Convention on Laundering, Search, Seizure and Confiscation of the Proceeds from Crime (CLSCPC) dari Council of Europe (Purwaning M. Yanuar, 2007).

Dalam CLSCPC, penyitaan diartikan sebagai sebuah hukuman atau tindakan, yang diperintahkan oleh pengadilan sebagai kelanjutan dari proses yang berhubungan dengan pelanggaran pidana atau pelanggaran-pelanggaran pidana sebagai akibat dari pencabutan yang permanen atas kekayaannya. Pada hakikatnya, pengembalian aset tidak hanya merupakan proses, tetapi juga merupakan penegakan hukum melalui serangkaian mekanisme hukum tertentu. Menurut UNCAC sendiri, pengembalian aset hasil korupsi sendiri terbagi dalam empat tahap, yaitu: 1) Tahap pelacakan asset; 2) Tahap tindakantindakan pencegahan untuk menghentikan perpindahan aset-aset melalui mekanisme pembekuan dan penyitaan; 3) Tahap penyitaan; 4) Tahap penyerahan aset dari negara penerima kepada negara korban tempat aset diperoleh secara tidak sah.

Di antara barang yang akan dilelang, tercatat beberapa kendaraan dirampas dari mantan Kepala Koips Lalu Lintas (Kakorlantas) Polri Irjen Djoko Susilo. Di antaranya, Toyota Rush 1.5 S AT atas nama Seto Aji Ismoyo, Nissan Serena Highway Star AT atas nama Siti Maropah, Jeep Wrangler 4.0L AT atas nama Bambang Ryan Setiadi, dan Toyota Harrier 2.4 AT atas nama M. Zaenal Abidin. Djoko Susilo merupakan teipidana kasus korupsi proyek simulator surat izin mengemudi (SIM). Sebanyak 48 aset jenderal bintang dua itu dirampas negara lantaran terbukti dalam kasus tindak pidana pencucian 
uang (TPPU) yang divonis hakim Pengadilan Tipikor Jakarta pada 2013. Hakim memvonis Djoko terbukti membeli aset dari hasil korupsi dan diatasnamakan orang lain.

Selain aset Djoko, KPK melelang sejumlah aset atas nama PT Citra Mandiri Metalindo Abadi, rekanan proyek simulator SIM. Aset itu berupa mobil Toyota Innova V Diesel AT 2012 warna abu-abu metalik atas nama PT Citra Mandiri Metalindo Abadi. Lelang akan dilakukan dengan perantara Kantor Pelayanan Kekayaan Negara dan Lelang (KPKNL) Jakarta III. Selain mobil, KPK akan melelang sejumlah barang lain. Di antaranya, handphone merek Samsung model GT193000, Samsung model GT-E1205T, Apple iPhone 5 model MD 299ID/A, dan telepon genggam BlackBerry. Tidak hanya itu, komisi antirasuah tersebut juga melelang satu koper merek Rimowa model Salsa Multiwheel dan Del Hybrid serta tas Chanel.

Beberapa aset yang dilelang juga dirampas dari koruptor lain. Di antaranya, mantan Bupati Bangkalan Fuad Amin dan eks Ketua Komisi D DPRD DKI Jakarta M. Sanusi. Febri menjelaskan, sebelum proses lelang, KPK lebih dahulu mengumumkan nilai limit Cfloor price) atau harga terendah. Misalnya, Volkswagen Golf 1.4 bernilai limit Rp 131,6 juta, Volkswagen Beetle 1.2 memiliki nilai limit Rp 286,75 juta, Honda CR-V 2.4 dengan nilai limit Rp 76,6 juta, dan Honda Civic FD2 2.0 dengan nilai limit Rp 78 juta.

Hal tersebut dilakukan untuk pengembalian aset negara akibat korupsi, maka KPK membuka lelang eksekusi barang rampasan kasus rasuah. Mayoritas aset yang dilelang berupa kendaraan. Balikan, sebagian masuk golongan mobil mewah senilai ratusan juta hingga miliaran rupiah. Total ada 22 aset yang masuk daftar lelang, agar uang hasiol lelang tersebut akan dikembalikan ke keuangan negara dan tidak menjadi tumpukan yang menganggu dan menyita keuangan negara untuk merawatnya.

\section{PENUTUP}

Tindak pidana korupsi sering disebut extra ordinary crime, sering kali tindak pidana korupsi ini diidentikkan dengan white collar crime yaitu suatu perbuatan (tidak berbuat) dalam sekelompok kejahatan yang spesifik yang bertentangan dengan hukum pidana yang dilakukan oleh pihak professional, baik oleh individu, organisasi, atau sindikat kejahatan, ataupun dilakukan oleh badan hukum. Kerugian negara akibat tindak pidana korupsi masih belum tertutupi dan keresahan masyarakat masih tinggi terhadap penegakan hukum atas tindak pidana di Indonesia. Korupsi sering disebut extra ordinary crime, sering kali tindak pidana korupsi ini diidentikkan dengan white collar crime yaitu suatu perbuatan (tidak berbuat) dalam sekelompok kejahatan yang spesifik yang bertentangan dengan hukum pidana yang dilakukan oleh pihak professional, baik oleh individu, organisasi, atau sindikat kejahatan, ataupun dilakukan oleh badan hukum. Untuk pengembalian aset negara akibat korupsi, Komisi Pemberantasan Korupsi (KPK) membuka lelang eksekusi barang rampasan kasus rasuah. Mayoritas aset yang dilelang berupa kendaraan. Bahkan, sebagian masuk golongan mobil mewah senilai ratusan juta hingga miliaran rupiah. Total ada 22 aset yang masuk daftar lelang. Persoalan asset recovery untuk meminimalkan kerugian negara merupakan merupakan faktor yang tak kalah penting dari upaya pemberantasan korupsi di samping memvonis pelaku dengan hukuman yang seberat-beratnya. Langkah untuk meminimalkan kerugian negara tersebut di samping hams dilakukan sejak awal penganan perkara dengan pembekuan dan penyitaan, juga mutlak dilakukan melalui keija sama dengan negara lain di mana hasil kejahatan (proceeds ofcrime) berada. 


\section{Daftar Pustaka}

\section{Buku}

Achmad Zainuri, 2007, Akal Kultural Korupsi di Indonesia, Cahaya Baru Satvangan, Depok.

Adrian Sutendi, 2010, Hukum Keuangan Negara, Sinar Grafika, Jakarta.

Andi Hamzah, 1991, Korupsi di Indonesia Masalah dan Pemecahannya, Gramedia Pustaka Utama, Jakarta.

Arief Barda Nawawi, 201.0, Bunga Rampai Kebijakan Hukum Pidana, PT. Citra Aditya Bakti, Bandung.

Deni Styawati, 2008 , KPK Pemburu Koruptor, Pustaka Timur, Yogyakarta.

E.Y Kanter dan s. R. Sianturi, 2002, Asas-asas hukum Pidana di Indonesia dan Penerapannya, Penerbit Stoi'ia Grafika, Jakarta.

lirensm ‘:krYn 19 ؟., G, Penegakan Hukum dan Kesadaran dan Masyarakat, Deepublish, Yogyakarta.

IIRWSYYY?.Mu o I m, Kejnbuga-Lembaga Negara Independen di Dalam Undang-Undang Dasar Republik Indonesia Tahun 1945, Deepublish, Yogyakarta.

Nyoman Serikat Putra Jaya, 2008, Sistem Peradilan Pidana (Criminal Justice System), Semarang.

YMimgl Nur, $m$, Pengembalian Aset Hasil Korupsi: Berdasarkan Konvensi PBB Anti Korupsi 2005

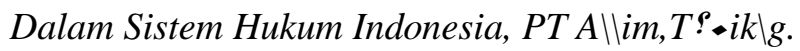

Ralrmat Soemitro, 1987, Peraturan dan Instruksi Lelang, PT. Eresco, Bandung.

loi ktumita., 21>, Pengkajian Hukum, tentang Kriminalisasi, Pengembalian Aset, Kerja Sama Internasional dalam Konvensi PBB, V>•aAi PembVn Issi Nasional, Departemen Hukum dan Hak Asasi Manusia, Jakarta.

Salim HS, 2011, Perkembangan Hukum Jaminan di Indonesia, Rajawali Pers, Jakarta.

Soerjono Soekanto datr Sri Mamudji, 2011, Penelitian Hukum Normatif, Rajawali Pers, Jakarta.

Zainuddin Ali, 2010, Metode Penelitian Hukum, Sinar Grafika, Jakarta.

\section{Jurnal dan Hasil Penelitian}

Gokma Toni Parlindungan s. Wewenang Jaksa Penuntut Umum Dalam Penanganan Perkara Korupsi, Volume 5, Nomor 2, 2013.

dma. T om TivTigi `’, Sanksi Administrasi Bag'i Wajib Pajak Pettghasilan Orang Pribadi Di Kota Padang, Jurna'l Advokasi, Volume 5, Nomor 2, 2014. 
Gokma Toni Parlindungan S, Pembagian Kekuasaan Dalam Hukum Tata Negara Indonesia, Jurnal Advokasi, Volume 7, Nomor 2, 2016.

Gokma Toni Parlindungan S, Tinjauan tentang Pemeriksaan Saksi Dakam Perkara Pidana, Jumal Advokasi, Volume 8, Nomor 2, 2017.

Gokma Toni Parlindungan S, Prinsip-Prinsip Negara Hukum dan Demokrasi Dalam Pembentukan Peraturan Daerah, Jumal Hukum Respublica, Volume 16, Nomor 2, 2017.

Harkristuti Harkrisnowo, Rekonstruksi Konsep Pemidanaan: Suatu Gugatan terhadap Proses Litigasi dan Pemidanaan di Indonesia, Disampaikan dalam Orasi Pada Upacara Pengukuhan Guru Besar Tetap dalam Ilmu Hukum Pidana FHUI di Balai Sidang UI, Depok, 2003.

Laurensius Arliman S, Kodifikasi RUUKUHP Melemahkan Komisi Pemberantasan Korupsi, UIR Law Review, Volume 2, Nomor 1, 2018.

UN Press Release, diterbitkan pada saat adopsi UNCAC, 31 Oktober 2003. 